\title{
obituary
}

\section{Ivor Isaac}

IVOR ISAAC, Professor of Botany in the University College of Swansea and Vice-Principal of the College from 1973 to 1977 died on 4 August 1978 at the age of 63 .

$\mathrm{He}$ was a Swansea man born, bred and educated in the City. From Dynevor School he entered the University College of Swansea in 1934 and graduated with first class honours in botany. Isaac then trained as a teacher and taught for a short time afterwards but in 1940 he was awarded an A.R.C. Scholarship to work at Cambridge on plant pathology under the supervision of Professor F. T. Brooks. Two years later, Isaac moved to East Malling Research Station as a plant pathologist where he continued his studies for a Cambridge $\mathrm{PhD}$ on the plant wilt diseases caused by the fungus Verticillium: these studies determined Isaac's subsequent career.

After three years at East Malling, Isaac returned to school teaching at Cheltenham but in 1947 he was appointed Senior Lecturer in Biology at Acton Technical College which was later developed into Brunel University. While there, Isaac was responsible for the planning of the new Department of Biology at Brunel. However, in 1950 the opportunity came to return to Swansea first as lecturer in botany and subsequently as reader and professor in the University College. There Isaac played his full part in the development of a rapidly growing department and he pursued his researches on Verticillium wilt diseases so successfully that he soon became recognised internationally as one of the leading experts on this important pathogen.

Isaac's early work centred on clarification of the taxonomy of Verticillium isolates. At that time, there was considerable confusion because it was not clear whether the two most destructive pathogens in the genus viz. $V$. alboatrum and $V$. dahliae, were forms of the same organism or were two distinct species. By using morphological, physiological and pathological criteria, Isaac established convincingly that these organisms are distinct species. A distinguished fellow worker wrote subsequently that this work brought order out of chaos.

Isaac continued, with the help of research students, to study many different aspects of the vascular wilt diseases caused by Verticillium both in the United Kingdom and overseas. The studies were extended to a wide range of host plants often of great economic importance, such as lucerne and potato. The studies resulted in a continuing series of papers covering the ecology and survival of the fungus in the soil, the etiology of the disease, methods of control and the prevention of dissemination.

Isaac's reputation as a plant pathologist led to invitations to visit and advise in several countries including Italy, Malaya, India and the United States. Shortly before his death he was collaborating closely with the U.S. Department of Agriculture on an outbreak of Verticillium wilt on American lucerne crops. He served on several committees concerned with plant pathology and he played a leading part in the establishment of the first International Conference on Verticillium.

Isaac was no narrow academic. In his early years he was a very considerable soccer player and he captained both the Cambridge University team and the war-time combined Oxford and Cambridge XI. In later years in Swansea he was always deeply concerned with adult education and he frequently taught extra-mural courses himself. $\mathrm{He}$ was a man with many friends. His warm sympathetic personality was combined with high academic ability and clarity of thought; these qualities were much appreciated by colleagues and by students at all levels. $\mathrm{He}$ is survived by his wife Catherine, by three sons and a daughter.

J. M. Milton

\section{W. Kent-Jones}

Dr Douglas William Kent-Jones, O.B.E., F.R.I.C., died peacefully in Ealing on 31 August 1978, aged 87. $\mathrm{He}$ was one of the pioneers of the application of science to cereal technology and was recognised internationally as an authority on cereal chemistry. Indeed his book Modern Cereal Chemistry testifies to his immense knowledge of his subject.

In the 1914-18 war he served in the Royal Fusiliers, the Special Brigade of the Royal Engineers and the Royal Flying Corps. It was during this time he claimed he learned his great capacity for getting on with others, and it was this capacity that spurred him throughout his long and active life to give generously of his time to many professional bodies. Thus he was honorary Treasurer of the Royal Institute of Chemistry (1946-53) and its President from $1955-57$. He was honorary secretary of the food division of the Chemistry Section of the International Union of Pure and Applied Chemistry, Chairman of the Council of the British Industrial Biological Research Association (1966-70) and its President from 1970-72. In 1971 he was awarded the biannual Gold Medal of the Society of Chemical Industry and in 1974 he received the O.B.E. for his services to the food industry.

During the greater part of this time he was (until he reached the age of 75) the senior partner of the highly successful analytical and consulting chemists, D. W. Kent-Jones and A. J. Amos. After the 1914-18 war he had been chemist, and later director, of a firm in Dover associated with the milling and baking industries and in 1931 he formed the practice, specialising in cereals, first from laboratories in Dover, later in Ealing, and finally the spacious and well-equipped premises in Dudden Hill Lane, London.

He learned his baking by working in small bakeries after his days work, and in 1935 published The Practice and Science of Breadmaking. From 192645 he was the Chief Examiner of Breadmaking to the City and Guilds of London Institute. During 1930-39 he travelled and lectured extensively, becoming involved in Procea Products Ltd. when in the Antipodes and when the Company was formed in the UK he became a director, and finally Chairman, retiring in 1965 . In 1938 he was awarded the Belgian Affront medal, and was made Professor honoris causa of the Institute des Industries de Fermentation. In 1947, at the request of the Bread Manufacturers of New South Wales, he advised on the setting up of the Bread Research Institute of Australia.

Wherever he went he was interested in measuring the qualities of flour and their relation to bread, cake and biscuit baking characteristics and he pub- 